\title{
SÕNA SAAVAD ENDISED PEATOIMETAJAD
}

\begin{abstract}
Ajakirja 60. sünnipäeva puhul küsisime endistelt peatoimetajatelt kaks küsimust: Millisena nägite peatoimetajana Keele ja Kirjanduse funktsiooni ühiskonnas? Kas see funktsioon on aja jooksul kuidagi muutunud?
\end{abstract}

\section{AKSEL TAMIM \\ Peatoimetaja aastatel 1983-1995}

On liigutavalt tore (tean küll, et tsiteerin) möödunud kuuekümnele aastale tagasi vaadates tõdeda, et Keel ja Kirjandus on keerukatest aegadest suutnud läbi tulla oma väärikust minetamata. Vaevalised kümnendid nõukogude primitiivse rahvalikkuse ja parteilisuse stampideoloogia ning paiguti väga pedantse tsensuuri tingimustes sundisid muidugi peale kalkuleerimist ja manööverdamist, aga Olev Jõe [peatoimetaja aastatel 1958-1983] sirgjooneline tõetunne häälestas toimetust veel ka siis, kui esimene peatoimetaja juba lahkunud oli.

Riigid tekkisid ja lagunesid, oleks võinud pühenduda ka suurejoonelisele arveteklaarimisele. Ajakiri jäi kummatigi oma tõetundliku, reaalset kultuuripilti arvestava käsitlusviisi juurde. Et nüüd iga number lausa väike laulupidu oleks olnud, seda ka ei julge kuulutada, aga väike kokkulaulmine ometi.

Sest kurnavalt peale pressivast „,sisult sotsialistlikust" oli selleks korraks lahti saadud, üha nõudlikumad ,ühtse nõukogude rahva" kujunemise üleskutsed olid kadunud asjade hulka arvatud.
Mingil hetkel tundus, et ees on ainult head, rõõmsad arengud. See oli siiski ainult hetketunne.

Nõukogude anneksiooni aegse väga sihiteadliku venestamise pärandina jäid kestma pinged rahvussuhetes. Üheksakümnendatel aastatel oli korduvalt kõne all siia (ka sundkorras) tulnud inimeste tagasiminek kodupaika. Kuid näiteks tolleaegne Venemaa peaminister Jevgeni Primakov oli väga kategooriline: ta deklareeris, et ümberasumine võib toimuda vaid suure kodumaa põhja- või idarajoonidesse, just seal on inimesi vaja. Ja üldse, lisas akadeemikust peaminister, otstarbekam on juurutada (vn укоренить) need inimesed sinna, kus nad praegu elavad. Tahan selle ajalookilluga osutada, kui mitmekülgne materjal ootab rahvusprobleemide uurijat. Migratsiooni ja remigratsiooni valdkond peaks tänast humanitaariat tõsiselt huvitama, sest asjade praeguse seisuga ei olda ju rahul, olukord tundub paljudele ikka veel ajutisena, mitme vene publitsisti väidete kohaselt ei ole o m a de ootamine veel hoopiski lõppenud. See kõik ei ole ainult Eesti riigi julgeolekupoliitika probleem, vaid $\mathrm{ka}$ meie kõigi igapäevase elu, tavasuhete, normaalse hubasuse küsimus. Niiviisi on see ka kultuuriajakirjanduse probleem. Rein Ruutsoo tegi omal ajal olulist tööd nõukogude rahvuspoliitika analüüsimisel. Mäletan, kuidas toimetajana püüdsin ta teravusi tsensuurikõlblikumaks nürida. Aga oluline jäi ikkagi kõlama. See on üks näide möödunud sajandi lõpu humanitaaria vahekorrast tegelikkusega. Ja eeskuju tänaseks, sest keerdsõlmed on ju alles. 
Toimetuse küsimuseleht, mis ajendas neid ridu, viitab ka humanitaaria võimalikule staatusemuutusele „ajastul, mil rahvuse mõistet üha enam küsimuse alla seatakse".

Nüüd aiman küll Olev Jõe rahulolematut värahtust. Siin näen ma tõepoolest tänapäevase kõrgpoliitika ja kõige igapäevasema argielu ning tavamõtlemise käeandmise vajadust. Liiga tihti algavad praegused mõtisklused otsekui enesestmõistetava konstateeringuga: ajal, mil rahvusriike peetakse anakronismiks - jne jne. Vanainimese kohtlane küsimus: kes ikkagi peab? Kes selle asja siis nii lõplikult ära on otsustanud?

Tsiteerides ka lõpetan: „Eestlane olen ja eestlaseks jään” ei olnud ju ometi niisama väike etteaste $a d$ hoc.

\section{MART MERI}

Peatoimetaja aastatel 1995-2006

Kui 1999. aasta augustis ilmus Keele ja Kirjanduse 500. number, tegi Eesti Päevaleht sellest vaat et ülekülje uudise. Kasutasin seal esimest korda väljendit vaimne julgeolek, öeldes, et selle üheks allikaks on kindlasti Keel ja Kirjandus. Paatoslik ja naiivne, ütlevad marksistid ja turufundamentalistid. Siiski jään endale truuks. Teisisõnu on see eesti asi, mille oleme kõige lühemalt kirja pannud oma põhiseaduse preambulis. Keele ja Kirjanduse, nagu ka teiste kultuuriajakirjade funktsioon ühiskonnas on hoida käigus enam-vähem argumenteeritud mõttevahetust teemadel ja valdkondades, ilma milleta kaoks pikkamisi põhjendus ka Eesti statistikaameti olemasolule. Üldjoontes pole see funktsioon ajakirja asutamisest saadik muutunud ega kao loodetavasti edaspidigi. Ajakirja asutamine 1958 langes ajale, mil toonased kultuurisõdalased olid taandumas ja sai moodustada avalikke lauseid, olgu akadeemilisi või esseistlikke, mis kõnelesid eesti asjast ja muustki ilmast pisut rohkem. Isegi etümoloogilised etüüdid muutusid avaramaks.

Ajapainet on vist alati, aga kui läbinägevus jääb lubatuks, kui filoloogilisi valdkondi ei suruta vabatahtlikult teadusbürokraatia kastidesse ning valdkonnavaheliste seoste esitamine on jätkuvalt oodatud, kui (toimetaja pilgu alt kõrvale jäänud) eksiväide pälvib tunnustatava vastulause, siis jääb Keel ja Kirjandus erguks. Hoolimata sellest, mis suunas areneb filoloogia Eestis või mis vormi võtab uus juba pungitav kultuurisõda. 2000-ndate alguse ajapaine oli akadeemiliste liigamängude hoogustumine ja artiklipunktide noppimine. Toimetuseni jõudsid need kaudse survena revideerida ajakirja tiitlit ja sisu sihiga eraldada taas keel kirjandusest, loobuda üksikutestki esseistlikest tekstidest ja allutada toimetus mõne kõrgkooli huvidele. Hea lihtne puhas lahendus, aga mitte aktsepteeritav, sest preambul pole ju tühipaljas paatos, vaid kõik see reaalsus, mis on Wiedemannis ja Saarestes, Tammsaarel ja Lutsul, ja igas Keele ja Kirjanduse numbris.

\section{JOEL SANG}

Peatoimetaja aastatel 2006-2016

Esiteks, kitsamalt võttes - milline on Keele ja Kirjanduse funktsioon Eesti humanitaarteadustes?

Kõik distsipliinid arenevad konservatiivsuse ja innovatsiooni pingeväljas. Kui mingis teadusharus valitseb ülekaalukalt alalhoidlikkus, siis toob see kaasa viljatuse. Ja teistpidi: kui keskenduda ainult uutmisele, siis kaotab distsipliin oma keskme ja identiteedi.

Viimastel aastakümnetel oleme haaranud innukalt kinni igast lääne moevoolust - see puudutab eeskätt kirjandusteadust - ja püüdnud neid kas või vägisi kohaliku ainese peal rakendada. Mõni selline katse on ehk avanud uusi vaatenurki, enamasti on aga tegemist kriitikavaba kopeerimisega. Keel ja Kir- 
jandus peaks siin ilmutama elutervet skepsist ja olema heas mõttes konservatiivne, et tagada vastavas valdkonnas tasakaal. Selles osas on ajakirja funktsioon aastatega tõesti muutunud: kui nõukogude aja sumbunud õhkkonnas oli teretulnud iga värske puhang vabast maailmast, siis nüüd tuleb esmajoones kaitsta eesti humanitaarse mõtte traditsioone.

Milline on Keele ja Kirjanduse roll ühiskonnas? Kui väljenduda pidulikult, siis on ta kutsutud ja seatud teenima eesti rahvast, tema keelt ja kultuuri. Konkreetsemaks minnes on ta ülesanne vahendada meie keele- ja kirjandustead- laste ning folkloristide uurimistöö tulemusi, pakkudes neile laiemat auditooriumi kui kitsalt erialased väljaanded. Kuid asja tuleb vaadata ka teisest otsast, silmas pidades lugeja huve. Pahatihti on mõni uurimus nii erialane ja ahta fookusega, et läheb korda vaid paarile autori kolleegile. Et säilitada sedagi väikest lugejaskonda, mis Keelel ja Kirjandusel veel on, peaks ajakiri avaldama aegajalt suurema üldistusastmega kirjutisi - nagu neid on püüdnud pakkuda igaaastased temaatilised kaksiknumbrid - ja esseistlikke käsitlusi. Nende hankimine pole teadagi lihtne. 